\title{
Development of E-banking channels and market share in developing countries
}

\author{
Ali Nazaritehrani* (D) and Behzad Mashali
}

\author{
* Correspondence: nazari.tehrani@ \\ yahoo.com \\ Department of Management, \\ University of Science and Culture, \\ Park St., Ashrafi St., Tehran, Iran
}

\begin{abstract}
There is fierce global competition within the banking industry. Therefore, banks endeavor to grow and strive to increase their market share. We analyzed the effect of developing innovative channels of presenting bank services on banks' market share. The statistical population of this research was Shahr bank's central headquarter and its branches in Tehran, Iran. We developed questionnaires for gathering the data. The validity and reliability of the scales were tested by EFA, CFA, experts' opinion, and Cronbach's alpha. We used linear regression to assess the impact of innovative channels, including internet banking, automatic teller machines (ATMs), mobile banking, telephone banking (TB), and point of sales (POS) on banks' market share. The results indicated that some of these channels, including internet banking, POS, and TB, positively affect a bank's market share. The effect of two other platforms, including mobile banking and ATM development, on banks' market share was rejected. The findings of this study expand our understanding of how bank managers can improve their market share by developing innovative e-banking channels.
\end{abstract}

Keywords: E-banking channels, New banking services, Bank market share, Innovative services, Bank marketing

\section{Introduction}

Today, due to the global competition among financial organizations, market share plays a vital role in banks' success. Studies have recognized that a bank's market share is a key element of a bank's profitability, growth, and survival (Khan, Ahmad, \& Chan, 2018). It is also considered as an indicator of a bank reputation (Dunbar 2000). According to Buzzell et al. (1975), possessing a large market share can result in creating economies of scale, market power, and management quality, which leads to a superb return on investment and a great profit. Therefore, striving to achieve a significant share of the whole market is of great importance for all banks and financial organizations wanting to grow and to survive in a competitive environment.

Studies have asserted that some elements, such as customer satisfaction (Anderson et al. 1994; Rust and Zahorik 1993), brand extension (Smith and Park 1992), dynamic marketing methods (Davcik and Grigoriou 2016), customer retention (Rust and Zahorik 1993), and forming joint ventures (Shen and Cheung 2018), highly influence market share. In general, an organization can boost its market share by lowering its prices, and/or by improving its product and service quality (DeYoung and Nolle 1996). Financial organizations can take advantages of most innovative technologies for a 
variety of activities from financial regulation (Chao et al. 2019) to providing services (YuSheng and Ibrahim 2019; Laukkanen and Lauronen 2005). By the means of new technologies, to increase service quality, and consequently, increase market share, banks can present their services through innovative channels like electronic banking (hereafter e-banking) and its components (Bloemer et al. 1998).

Although it is claimed that banks should improve their services (Bloemer et al. 1998) to increase market share, there is little research on the relationship between the different channels of presenting innovative banking services and a bank's market share. The current literature on bank marketing considers innovative banking services agents of bank growth, but it neglects the effect of developing various channels of innovative services on a bank's market share. In addition, most of the studies of innovative banking services were performed in developed countries. Chen and Puttitanun (2005) asserted, however, that developing countries may radically differ from developed countries when exerting and exploiting innovation. It is useful to study the relationship between the development of ebanking channels and bank market share in developing countries like Iran.

Based on the above discussion, we theorized that the development of e-banking channels, including Automated Teller Machines (hereafter ATM), Point-of-Sales (hereafter POS), internet banking, telephone banking (TB), and mobile banking (Abor 2005; Agwu 2018; Felix 2018; Kashmari et al. 2016), positively influences banks' market share. In this study, we outlined how the development of e-banking platforms may affect increasing banks' market share, and addressed this issue by analyzing data collected from 154 experts at branches of Shahr bank in Tehran, Iran. The units of analysis in this study were the Shahr Bank branches. Based on rankings published by the Central Bank of the Islamic Republic of Iran, ${ }^{1}$ Shahr bank is the most innovation-driven bank in the Iranian banking industry, and therefore it was the best environment for performing this research.

This article contributes to the theory and practice within the domains of bank marketing. This research contributes to bank marketing literature and practice in two ways. First, this research helps develop a better understanding of whether innovative banking services can influence marketing concepts like market share by combining Agwu (2018), Felix (2018), Abor (2005), and Kashmari et al.'s (2016) e-banking channels. Second, by revealing the direct impact of each e-banking platform on market share, this article will enable bank managers and authorities to make their market grow by means of improving their innovative service channels.

\section{Theoretical background and hypotheses}

Organizations always pursue success and growth. One of the fundamental factors of an organization's success, survival, and growth in a competitive market is market share. According to the resource-based theory of competitive advantage, firms apply their resources to boost their position against their competitors to gain competitive advantages and a greater share of the market (Grant 1991). In studies, market share has been mentioned as an important agent of company performance. Studies have confirmed that there is a positive relationship between market share and economic profit (Dunbar 2000). The market share of corporations has, also, a vital role in setting the equilibrium price. That is, the more corporations in the market with less market share, the better 
the market movement towards a competitive market (Tash et al. 2014); it should be noted that the banking industry is not an exception (Bahrami et al. 2014).

In general, absolute market share and relative market share are two different types of market share. Absolute market share is defined as the number of customers (or the cash value achieved from those customers) compared to the total number of customers (or the cash value of the total sales in the market) (Kaplan and Norton 1996). Relative market share measures the organization's sales or cash value compared to the organization that has the largest market share in the same market, or to the market share of three large rivals (Rawash 2012). Overall, a large market share is the consequence of the prosperous accomplishment of a competitive strategy and the corollary of a company's market growth (Ghemawat 2002).

Bahrami et al. (2014) believed that some factors, including human factors, bank facilities, technology, bank services, bank accessibility, and physical factors, can affect the bank market share. As mentioned earlier, some key elements, such as customer satisfaction (Anderson et al. 1994; Rust and Zahorik 1993), brand extension (Smith and Park 1992), dynamic marketing methods (Davcik and Grigoriou 2016), customer retention (Rust and Zahorik 1993), forming joint ventures (Shen and Cheung 2018), low prices, and a high quality of products and services (DeYoung and Nolle 1996), can significantly influence the growth of a bank's market share. Moreover, obtaining market share is not simple for firms or for their competitors (Maymand and Fard 2015). Banks are prone to technological obsolescence, and market share is a backward-looking metric (Maymand and Fard 2015). As a result, banks should respond to economic and technological changes rapidly to maintain and improve their market share in the future (Kajuju 2016).

Information Technology (IT) is the most important cause of changes in the worldwide banking system (Argamo 2015). In this situation, if banks take advantage of the benefits of various service channels and a combination of innovative IT-based solutions as their main strategy, they will obtain a greater share of the market (Gupta 2013). Therefore, banks should present new banking services through innovative channels to remain competitive, create excess added value (Laukkanen and Lauronen 2005), and achieve a greater share from the market (Cetina and Mihail 2007).

In the literature, new banking services are referred to in various terms, such as novel banking services (von Hippel and Riggs 1996), innovative banking services (Kashmari et al. 2016), new banking services (Prugsaapron 2015), and modern banking services (Miranda-Petronella 2009). New banking services are defined as services that utilize modern instruments, platforms, and channels to present banking services to customers (Tash et al. 2014). New banking services are not supposed to be substitutions for traditional types of banking transactions. However, there are many advantages to IT-based services, since they can enhance the quality of services and decrease delivery costs (González et al. 2008). The main benefit of applying information technology and innovative solutions in the banking sector is the improvement of the efficiency and effectiveness of services (Mahmoodi and Naderi 2016) because traditional banking activities are all accomplished manually, and factors related to human mistakes can have a negative effect on banking transactions. Some of the benefits of new banking services include the reduction of the customer wait times at physical branches, a decrease of banks' physical extensions need, a reduction in the delivery service time, progress in 
banking transactions and customer tranquility, and a decrease of human-generated mistakes (Hosseini and Mohammadi 2012). Moreover, due to all of these advantages, and despite the trust issues in applying innovative electronic channels, there has been growth in the number of e-banking users (Laukkanen and Lauronen 2005).

Several studies have discussed electronic banking and its innovative channels. Hanafizadeh and Zare Ravasan (2018) worked on e-banking outsourcing and found that there are several factors affecting e-banking services outsourcing. They identified 23 key factors affecting e-banking outsourcing decisions and they categorized those into three clusters: technological attributes, organizational attributes, and environmental attributes. Hoehle et al. (2012) reviewed 247 articles about electronic banking that had been published in the most credible journals in the last three decades. They assessed various theoretical grounds and methods used in those articles for researching e-banking adoption. They suggested that, in order to improve electronic banking research, future studies should try to apply different theoretical approaches rather than the extant theories that they already covered. They considered ATMs, telephone banking, internet banking, and mobile banking as key channels of electronic banking. Recently, Li et al. (2017) performed research on the effect of digital banking start-ups on the efficiency of the retail banking system in the United States. They discovered that funding digital banking start-ups (FinTech) has a positive effect on a bank's stock returns. They asserted that instead of substitution, FinTech can be complementary to traditional banking. Sathye (1999) investigated the factors affecting internet banking adoption in Australia. He discovered that the most important barriers to more use of internet banking in Australia are security doubts and ignorance about internet banking and its profits. Furthermore, Nui Polatoglu and Ekin (2001) studied the conditions of internet banking and its acceptance in Turkey in terms of consumer-related factors and organizational factors. They found that internet banking significantly reduces banks' operational costs and increases customer satisfaction and customer retention. Their results also showed that internet banking plays a strategic role in the banking sector in emerging economies. In addition, Tiwari et al. (2007) studied the effect of innovative business approaches to banking services on the attainment of a competitive advantage. They delineated the important role of innovative solutions (especially mobile banking) in boosting the position of financial organizations in the market. In Table 1, a brief summary of previous studies in the field of e-banking is shown.

Innovative channels of delivering e-banking services include POS, ATMs (or out of branch services generally), mobile banking, telephone banking, and internet banking (Abor 2005; Agwu 2018; Felix 2018; Kashmari et al. 2016). Thus, we hypothesized how the development of these innovative channels of e-banking services can affect a bank's market share. The theoretical model is shown in Fig. 1.

\section{Point-of-sales (POS) terminals}

One of the most prevalent channels of providing new banking services is the POS terminal, which is an electronic device used for credit and/or debit cards transactions at retail locations, such as shops, restaurants, and hotels. It enables customers to perform banking transactions using their credit or debit cards, $24 \mathrm{~h}$ a day (Kajuju 2016). A POS terminal generally connects to the bank's main server through a telephone line or other 
Table 1 Summary of previous research

\begin{tabular}{lll}
\hline Researchers & Year & Findings \\
\hline Sathye & 1999 & $\begin{array}{l}\text { The most important barriers to increasing the number of } \\
\text { bank customers with e-banking services are security doubts } \\
\text { and ignorance about e-services profits. }\end{array}$
\end{tabular}

Nui Polatoglu \& Ekin

Tiwari, Buse, \& Herstatt

González, Mueller, \& Mack

Hoehle, Scornavacca, \& Huff

Mahmoodi \& Naderi

Li, Spigt, \& Swinkels

Hanafizadeh \& Zare Ravasan
Internet banking significantly reduces operational costs and increases customer satisfaction and customer retention, especially in emerging economies.

Innovative business approaches, like new banking services, simplify strategic goal attainment and can create a competitive advantage for companies and banks.

E-banking positively affects service quality and decreases service delivery costs.

The main channels of electronic banking are ATMs, telephone banking, internet banking, and mobile banking; to improve ebanking research, researchers should consider these channels and apply various theoretical approaches utilizing them.

Using IT in the banking industry improves the efficiency and effectiveness of services.

Funding of digital banking startups positively affects banks' stock returns.

Three clusters, technological attributes, organizational attributes, and environmental attributes, are the main considerations in developing e-banking services and outsourcing them.

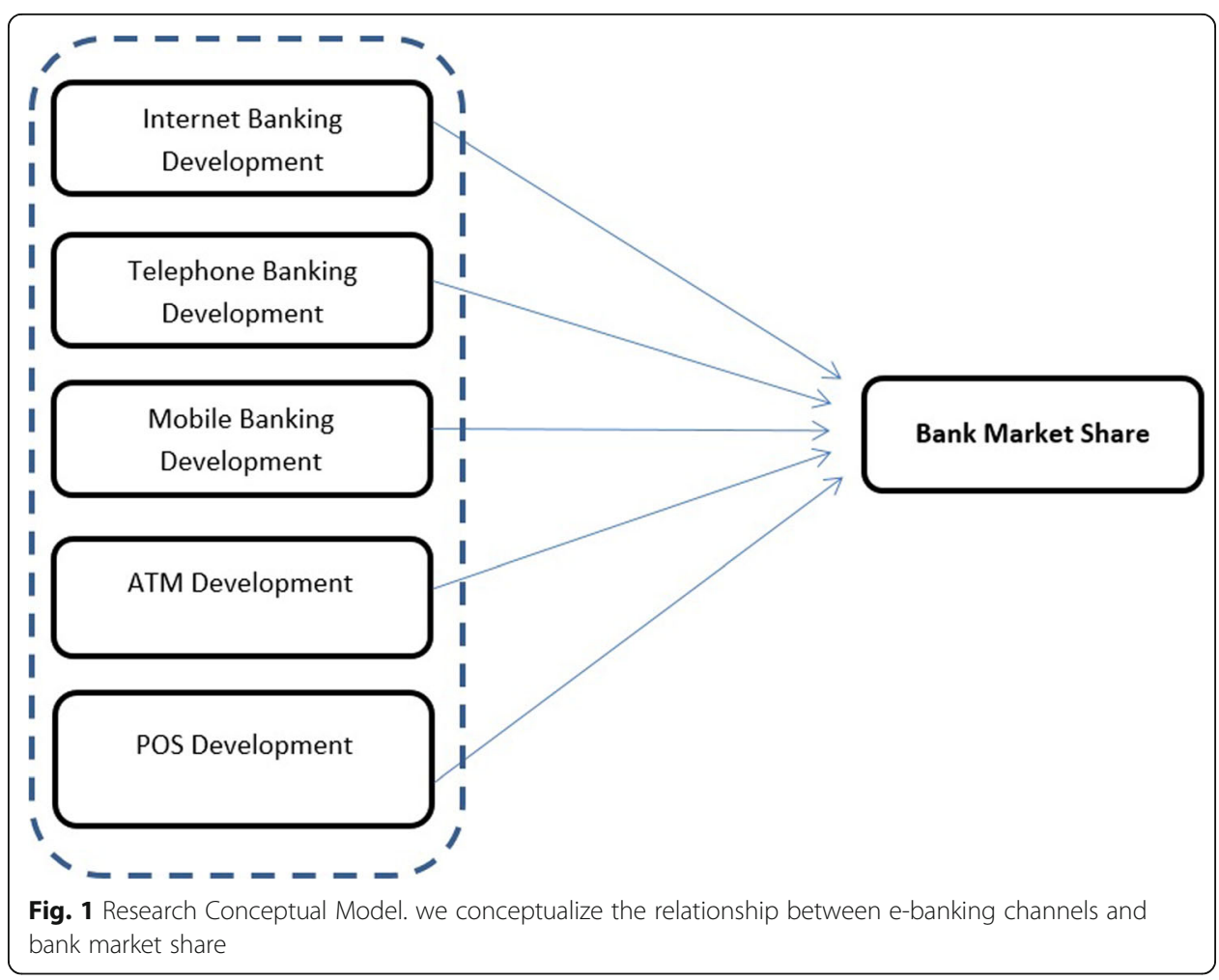


types of communication, like wireless connections, and transfers money from a buyer's account to the merchant's account (Hosseini and Mohammadi 2012). POS terminals are accessible, and they significantly facilitate banking transactions; thus, they can lead to improvement of the bank's market share (Bahrami et al. 2014). We therefore derived the following hypothesis:

\section{H1: The development of POS terminals has a positive effect on increasing a bank's} market share.

\section{Automated teller machines (ATMs)}

The other channel of e-banking is the ATM. An ATM is defined as an automated telecommunication device that enables consumers to access banking services without any need for a bank operator (Sarlak 2010). Sasidharan and Mathews (2008) discussed the advantages of ATMs, such as access to various banking operations, fund withdrawals, bill payments, fund deposits, access to statements, and 24-7 banking services. ATMs are also convenient, innovative, safe, and play a role as a value-added service to attract many new clients. Therefore, according to González et al. (2008), because there is no need for a bank operator, ATMs decrease service costs. Consequently, based on DeYoung and Nolle (1996), ATMs can increase the bank market share. As Bahrami et al. (2014) discussed, out-of-branch service accessibility and other physical factors of banking services can lead to an increase in the bank's market share. Moreover, ATM services can be found in every location (Sharma, Sharma \& Khan, 2019; Singanamalla et al., 2019); thus, developing ATMs can strengthen service accessibility. We derived the second hypothesis:

H2: The development of ATMs has a positive effect on increasing a bank's market share.

\section{Mobile banking}

Mobile banking is a service provided by financial companies, and it allows customers to benefit by using their mobile phone devices to perform banking transactions such as transferring funds, saving money, and paying bills. Pousttchi and Schurig (2004) defined mobile banking as a way of administering financial services via mobile technology. Mobile banking is accessible through short message service (SMS) technology, wireless application protocol (WAP), and mobile applications (Scornavacca Jr and Barnes 2004). In its initial form, it let customers obtain information about their accounts and transactions via SMS. Thereafter, financial institutions provided a wider diversity of financial services through WAP- and Java-enabled mobile phones (Mallat et al. 2004).

Mobile banking has many benefits. As a case in point, the problem of inaccessibility to physical branches has vanished because of these kinds of practical and frugal services. Consequently, financial services are available to the majority of people (Morawczynski and Pickens 2009). Furthermore, mobile phones have improved service quality, since customers can accomplish transactions whenever they want (Schierholz and Laukkanen 2007). Moreover, mobile banking has a high potential for providing additional banking services and should be further developed by banks (Brown et al. 2003). Therefore, based on DeYoung and Nolle (1996) and Bahrami et al. (2014), mobile 
banking can significantly contribute to a bank's market share. As a result, we developed the following hypothesis:

H3: The development of mobile banking has a positive effect on increasing a bank's market share.

\section{Internet banking}

Internet banking is defined as the acquisition of banking services via the internet. It provides a vast range of potential advantages because of the attainable and userfriendly application of technology (Yiu et al. 2007). It handles banking transactions on the internet via websites (Sarlak 2010). Clients have direct access to the bank's information system from anywhere they have access to the internet. Internet banking provides various online services, such as balance enquiries, ordering checks, instructions for various services (such as balance transfer, opening accounts, perusing account balances), making payments (Argamo 2015), paying bills, transferring cash, saving and investing money (Kajuju 2016), printing statements (Martins et al. 2014), and other information related to accounts (Miranda-Petronella 2009).

Internet banking has numerous benefits, such as faster marketing because of the easier access to customers, simpler launching of new services, a wider propagation of information (Gomez 2011), competitive advantages, attracting and retaining clients, higher revenues, fewer costs (Simpson 2002), a higher potential to economize time (MirandaPetronella 2009), a high capacity of innovation, improved communications, and higher customer satisfaction and loyalty (Thulani et al. 2008). This channel enables consumers to have most of their banking needs met with a minimum of human intermediation (Tan and Teo 2000). In general, internet banking enables banks to form and maintain an effective relationship with their clients and to lessen operating costs and fixed costs (Mols 1999). Therefore, according to Anderson et al. (1994), Rust and Zahorik (1993), and DeYoung and Nolle (1996), all the above-mentioned benefits of internet banking can help banks achieve a greater market share. We therefore developed the following hypothesis:

\section{H4: The development of internet banking has a positive effect on increasing a bank's} market share.

\section{Telephone banking}

The last channel studied in this research was telephone banking (hereafter TB). TB is a service that enables clients to accomplish some banking transactions like applying for account balance information or transferring money through the telephone (Hosseini and Mohammadi 2012). The origin of TB dates back to October 1989; in that year, Midland Bank Plc., which operated in the mature UK banking sector, made a drastic innovation and connected the first direct telephone banking subsidiary in Leeds (Doyle and Bridgewater 2012). For over 3 decades, telephone banking has played an important role as a useful banking feature, and almost all banks have endeavored to provide TB as one of their main services (Alikhani et al. 2013). TB has several positive characteristics. It can provide customers with access to data, personal information, personal accounts, and several banking services, like transferring money (Mahmood, 2019). TB services do 
not need physical places, and they are accessible all day and night (Rabiu et al., 2019). Bahrami et al. (2014) said that proper banking facilities, accessibility, and other physical factors can lead to an increase in market share; therefore, TB can positively influence a bank's market share. This led us to derive the fifth hypothesis:

\section{H5: The development of telephone banking has a positive effect on increasing a bank's} market share.

\section{Methodology}

\section{Sample}

The sample of this study comprised 182 managers, deputies, and experts of Shahr bank from its branches in Tehran, Iran; the units of analysis were the individual Shahr Bank branches. We selected an Iranian context because Iran is a developing country, and as Chen and Puttitanun (2005) asserted, people in developing countries may differ in using and welcoming innovative banking services. This made Iran a suitable context for our study. There are several banks in Iran, and experts at the Central Bank of the Islamic Republic of Iran ${ }^{2}$ found that the most innovative bank in Iran is Shahr bank. Therefore, it was a best place to study innovative banking channels in Iran. The sampling methods used in this research were geographical clustering and simple random sampling. First, the branches in Tehran were divided into 3 regions (according to the Shahr bank divisions), and then branches were randomly selected within each region.

\section{Data collection}

We divided our questionnaire into 2 booklets, 1 for independent variables, and the other for the dependent variable. The first booklets were hand-delivered to 182 managers of Shahr bank at its branches and gathered a week later in July 2016, and the second booklets were distributed among the same people, from 3 days after gathering the first booklets to 2 weeks later. When we gathered the first and second booklets, we wrote each respondent's branch number on the cover page of each booklet so we could match the first and second booklets of every respondent because we collected data from a single person at every branch. We used this method to avoid common method biases. Like other surveys, some respondents did not properly respond and return the questionnaires, and some questionnaires were flawed. There were 154 usable sets of booklets among 182 respondents, so the response rate was $85 \%$.

To ensure that non-response bias did not affect the study, we used t-tests on the mean discrepancies between the early respondents and late ones. Fortunately, the study observed no statistically significant differences between them. Furthermore, as noted above, we collected our data in 2 segregated booklets, 1 for the independent variables and 1 for the dependent variable, and at 2 different times to minimize common method biases (Sakhdari and Burgers 2018). To check if CMB had affected our data, we used Harman's single factor test, in which we loaded all items measuring latent variables into 1 common factor. The total variance for the single factor was 31.32 (less than 50\%), suggesting that $\mathrm{CMB}$ was not a concern in our study.

${ }^{2}$ www.cbi.ir 


\section{Measures}

A questionnaire was developed and used to collect the data from the respondents. It was hand-delivered to managers at the bank branches. The questionnaire was divided to 2 booklets. The first booklet was for gathering data about independent variables, including the development of mobile banking (5 items), ATMs (11 items), internet banking (6 items), TB (3 items), and POS (5 items). The second booklet included 17 expressions about the growth of the bank market share. In both booklets, participants were asked to show their opinions by the means of a Likert 5-point scale ranging from " 5 = strongly agree" to " 1 = strongly disagree". The scales are presented in the appendix at the end of this article. In the following section, we explain how we developed the scales.

Cohen et al. (1996) asserted that to properly develop new products/services, companies should allocate a great amount of resources, including time and financial resources, to them. We listed the aspects of new services of every channel of providing banking services, and, building on Cohen et al. (1996), we asked respondents to determine if Shahr bank has spent a great amount money and time to develop those services and to apply the most up-to-date and cutting-edge technological innovations over the last 5 years. To test the scale's validity, we used content validity as well as factor validity. Twelve booklets of questionnaires were distributed among experts, and we asked them for their opinions about the content of the measures. Their advice resulted in the modification of some questions. We also ran exploratory factor analysis (EFA) for all the scales, and it suggested a six-factor solution, which accounted for $65.2 \%$ of the variance in the variables $(\mathrm{KMO}=.70$; Bartlett's sig. $=.000$; Scree plot: the direction changed by a factor of 7). Since we had 5 scales, the sixth factor just accounted for $2.9 \%$ of the variance in the variables, and it was related to some rationally different items, so we decided restrict the EFA to 5 factors and eliminate 3 items that were related to the sixth factor from the ATMs, internet banking, and POS scales. We ran the EFA again and it confirmed a 5-factor solution (each scale's items in a distinct factor) that accounted for $62.3 \%$ of the variance in this variable $(\mathrm{KMO}=.74$; Bartlett's sig. $=.000$; Scree plot: the direction changed by a factor of 6). Items of each factor had a good correlation with each other, which confirmed the convergent validity of the scale. Table 2 shows the results of the EFA.

Then, we used Confirmative Factor Analysis (CFA) to assess the measurement validity. The results of the confirmative factor analysis suggested a reasonably good model fit $\left(p<0.001 ; \chi^{2} / \mathrm{df}=1.76 ; \mathrm{SRMR}=.068 ; \mathrm{RMSEA}=.063 ; \mathrm{CFI}=.904 ; \mathrm{GFI}=.909\right)$ for the independent variables and for the market share scale $\left(p<0.001 ; \chi^{2} / \mathrm{df}=2.24 ; \mathrm{RMSEA}=\right.$ .057 ; CFI $=.892$; GFI $=.912$ ). Figures 2 and 3 show the results of the CFA performed by AMOS.

To verify the discriminant validity, we applied the suggestion of Anderson and Gerbing (1988), who discussed that the discriminant validity can be confirmed through calculating the chi-square difference of an unconstrained model (in which items of each factor were loaded onto their intended indicator) with a constrained model (in which the correlation between the 2 constructs is limited to 1 [perfectly correlated]). The chi-square difference tests between internet banking and market share $\left(\Delta X^{2}(1)=34.215, \mathrm{p}<.001\right)$, telephone banking and market share $\left(\Delta \chi^{2}(1)=52.018, p<.001\right)$, POS banking and market share $\left(\Delta \mathrm{X}^{2}(1)=58.612, p<.001\right), \mathrm{ATM}$ banking and market share $\left(\Delta \mathrm{X}^{2}(1)=39.103, \mathrm{p}<.001\right)$, 
Table 2 EFA Results

\begin{tabular}{|c|c|c|c|c|c|c|}
\hline Scale & Item & Factor 1 & Factor 2 & Factor 3 & Factor 4 & Factor 5 \\
\hline \multirow[t]{5}{*}{ Mobile Banking } & 1 & .93 & & & & \\
\hline & 2 & .97 & & & & \\
\hline & 3 & .89 & & & & \\
\hline & 4 & .96 & & & & \\
\hline & 5 & .81 & & & & \\
\hline \multirow[t]{11}{*}{ Out of Branch (ATMs) } & 6 & & .83 & & & \\
\hline & 7 & & .95 & & & \\
\hline & 8 & & .81 & & & \\
\hline & 9 & & .87 & & & \\
\hline & 10 & & .96 & & & \\
\hline & 11 & & .95 & & & \\
\hline & 12 & & .79 & & & \\
\hline & 13 & & .91 & & & \\
\hline & 14 & & .94 & & & \\
\hline & 15 & & .82 & & & \\
\hline & 16 & & .91 & & & \\
\hline \multirow[t]{6}{*}{ Internet Banking } & 17 & & & .90 & & \\
\hline & 18 & & & .86 & & \\
\hline & 19 & & & .86 & & \\
\hline & 20 & & & .94 & & \\
\hline & 21 & & & .90 & & \\
\hline & 22 & & & .81 & & \\
\hline \multirow[t]{3}{*}{ Telephone Banking } & 23 & & & & .96 & \\
\hline & 24 & & & & .79 & \\
\hline & 25 & & & & .91 & \\
\hline \multirow[t]{5}{*}{ POS } & 26 & & & & & .93 \\
\hline & 27 & & & & & .94 \\
\hline & 28 & & & & & .88 \\
\hline & 29 & & & & & .75 \\
\hline & 30 & & & & & .91 \\
\hline Percent of Variance & & $12.2 \%$ & $31.3 \%$ & $7.8 \%$ & $5.6 \%$ & $5.3 \%$ \\
\hline
\end{tabular}

and mobile banking and market share $\left(\Delta \mathrm{X}^{2}(1)=32.034, \mathrm{p}<.001\right)$ were all statistically significant. Because the chi-square difference between each pair was far above 10.828 (the critical chi-square value for 1 degree of freedom at $p=.001$ ), it confirmed the discriminant validity of the main constructs in our study.

To develop the scale for measuring bank market share growth, we listed all indexes of the bank market share in Iran published by the Central Bank of the Islamic Republic of $\operatorname{Iran}^{3}$ (available in the appendix), and asked bank experts to determine the amount of growth of Shahr bank from 1 to 5 in every mentioned aspect. Cronbach's alpha was used to measure the corresponding reliability of all scales. As illustrated in Table 3, the results show that the scales are reliable. 


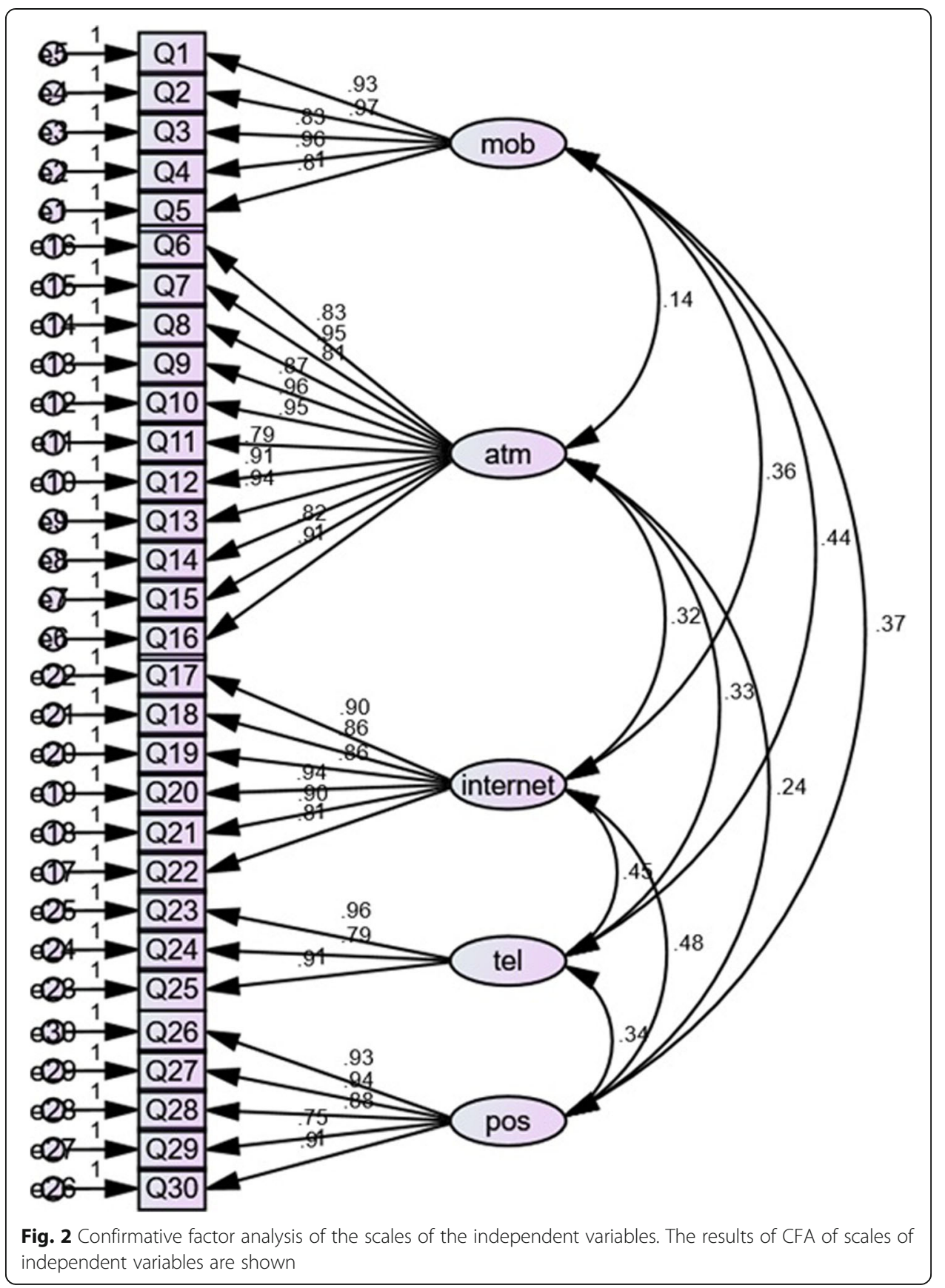

Data analysis method

Descriptive statistics, including frequencies and percentages, were used to describe the variables' characteristics. Moreover, inferential statistics (correlation and regression) were used to determine and to explain the relationships between the independent variables and dependent variable. This study used linear regression to test the hypotheses. Although we developed new scales, we did not test the whole structural model using SEM because in this case, the AMOS would present the indices of the goodness of the model fit for the whole model, while we wanted to get the goodness of the model fit for our measurement model, separately, in order to better develop our scales. Thus, 


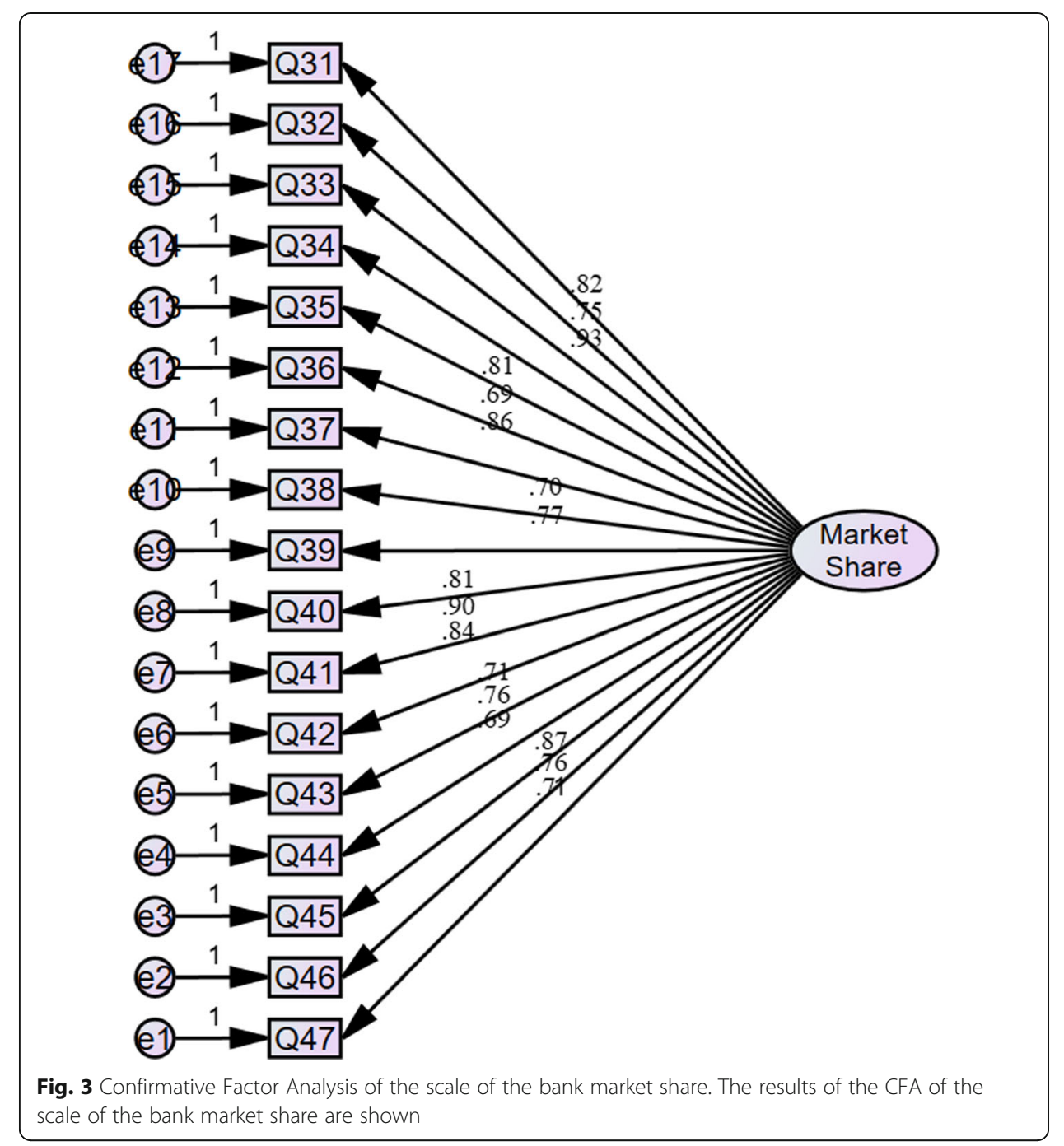

because our structural model was not a mediating model and was just a simple path analysis, we used the EFA and CFA to test our measurement model and regression to test our structural model.

\section{Results}

Table 4 demonstrates the means, standard deviations, and correlations for all variables used in this study. We calculated the Pearson correlation coefficients using SPSS software to estimate the general pattern of relationships between the variables and to check

Table 3 Reliability Alpha for Each Scale

\begin{tabular}{lll}
\hline Variables & Number of Items & Cronbach's Alpha \\
\hline Mobile Banking & 5 & .79 \\
ATM & 11 & .86 \\
Internet Banking & 6 & .79 \\
Telephone Banking & 3 & .73 \\
POS & 5 & .81 \\
Market Share Growth & 17 & .84 \\
\hline
\end{tabular}


Table 4 Means, Standard deviations, and Correlations of the Study Variables

\begin{tabular}{llllllllll}
\hline & & Mean & SD & 1 & 2 & 3 & 4 & 5 & 6 \\
\hline 1 & Mobile banking development & 3.82 & .58 & 1.00 & & & & & \\
2 & ATM development & 4.05 & .75 & $.32^{* *}$ & 1.00 & & & \\
3 & Internet banking development & 3.89 & .53 & $.28^{*}$ & $.35^{* *}$ & 1.00 & & \\
4 & Telephone banking development & 4.38 & .55 & $.24^{*}$ & $.16^{*}$ & $.34^{* *}$ & 1.00 & \\
5 & POS development & 4.49 & .50 & $.31^{* *}$ & .07 & $.12^{*}$ & $.38^{* *}$ & 1.00 & \\
6 & Market share & 4.53 & .62 & $.38^{* *}$ & $.16^{*}$ & $.45^{* *}$ & $.64^{* *}$ & $.64^{* *}$ & 1.00 \\
\hline$n=154$ & & & & & & & &
\end{tabular}

the probability of multicollinearity among them. The results of the correlation analysis show that the intercorrelations among the variables range from .07 to .64 , which suggests that multicollinearity is not a concern in the models. The study shows a significant relationship between the development of e-banking channels and market share growth. The highest of those is .64, which is related to POS, as well as telephone banking. The other correlation coefficients are $.45, .16$, and .38, which are related to internet banking, ATM, and mobile banking, respectively. Although the correlation of ATM development with bank market share is statistically meaningful, it is not significant; this variable is less likely to be able to predict an increase in the bank's market share in the regression model.

Linear regression was used to test the hypotheses. The results of the regression are given in Table 5. The dependent variable is the bank's market share and the predictors are internet banking development, TB development, mobile banking development, ATM development, and POS development. The regression model in Table 5 indicates that the development of innovative channels of banking services have a significant and positive impact on increasing the bank's market share. It shows that the regression model explains $93 \%$ of the variance in the market share growth, which is statistically significant $(p<.01)$. The model shows that internet banking (unstandardized $\mathrm{B}=.26$, $p<.01)$, telephone banking $(\mathrm{B}=.58, p<.01)$, and POS banking $(\mathrm{B}=.56, p<.01)$ have

Table 5 Linear Regression Results: Predictors of the Bank Market Share

\begin{tabular}{llll}
\hline & Regression Model & $\mathrm{t}$ & VIF \\
\hline Constant & $-1.06^{* *}(.145)$ & -7.314 & \\
Innovative e-banking channels & & & \\
Mobile banking development & $-.22(.113)$ & -1.919 & 2.247 \\
ATM development & $.04(.052)$ & .742 & 2.941 \\
Internet banking development & $.26^{* *}(.099)$ & 2.672 & 4.339 \\
Telephone banking development & $.58^{* *}(.073)$ & 7.872 & 4.912 \\
POS development & $.56^{* *}(.096)$ & 5.876 & 1.392 \\
Model statistics & & & \\
F & $394.92^{* *}$ & & \\
R square & .93 & & \\
Adjusted R square & .93 & & \\
\hline
\end{tabular}

$\mathrm{n}=154$, Unstandardized coefficients are reported. Standard errors are presented in parentheses Significance at ${ }^{*} p<.05,{ }^{* *} p<.01$ 
significant and positive effects on the bank's market share, providing support for Hypotheses 5,4 , and 1 , respectively. The results further show that the development of other innovative platforms, including ATMs and mobile banking, has no significant association with increasing the bank's market share. Thus, Hypotheses 2 and 3 were rejected.

\section{Discussion}

The purpose of this study was to investigate the effect of the development of new banking services on a bank's market share. Based on the marketing literature, scales were developed to measure the development of new banking services and the bank's market share. EFA, CFA, and Cronbach's alpha were performed to develop the proper scales. We distributed and collected 154 questionnaires from experts at Shahr Bank. Spearman correlation ratios and linear regression analysis were applied to analyze the data. The study illustrated that there is a significant correlation between platforms of new banking services and the bank's market share. Furthermore, the results showed that the development of 3 banking channels, including internet banking, telephone banking, and POS terminals, have a significant and positive impact on increasing the bank's market share.

\section{Theoretical implications}

The findings of this study shed light on the extent to which banks and financial organizations should concentrate on developing innovative channels of presenting their services to remain competitive and increase their market share. It contributes to the large, but still growing literature, on bank marketing. The first finding of this study indicates that internet banking development has a significant effect on a bank's market share. In a similar way, Gerlach (2000) found that internet banking can cut prices and result in a sustained competitiveness for traditional banks; however, our study assessed this relationship in a traditional developing country, which is of a great value.

The findings of this study provide further insight into whether the development of telephone banking helps banks to improve their position against their competitors. The results showed a significant relationship between TB development and bank market share growth. The results are in accordance with Alikhani et al.'s (2013) study, which asserted that telephone banking, as one of the most convenient channels of presenting banking services, could influence other components of bank marketing. Our study evaluated one of the most important components of bank marketing, which is the bank's market share.

The study also provides insight into how POS terminal development may influence the fate of a bank. The results illustrated that developing POS terminals would result in bank market share growth. The results did not support the effect of mobile banking and ATM development on banks' market share growth. This outcome contradicts Schierholz and Laukkanen's (2007) finding that mobile banking can improve service quality, customer convenience, and consequently, market share. It also conflicts with Thakur's (2014) exposition about the relationship between mobile banking and customer loyalty and market share. It may be the corollary of the fact that mobile banking has attained such a standard level that banks cannot differentiate their mobile phone 
services from those of other banks, and they cannot obtain a competitive advantage through mobile banking. In a similar line, ATMs are standardized, and their hardware parts are not developed by the banks themselves at all. It can explain why ATM development does not significantly affect a bank's market share, despite the fact that ATMs decrease service prices and improve accessibility (Massoud and Bernhardt, 2002).

\section{Managerial implications}

This study has several valuable implications for bank managers and authorities. In general, it suggests that bank managers wanting their bank market share to significantly increase should pay more attention to new channels of presenting innovative services. The findings of this study show that if bank managers keep their internet banking, telephone banking, and POS banking services up-to-date and continue to develop them, they can better and more easily attract and retain customers and increase their market share. In other words, as a promising and already prevalent channel of delivering banking services, internet banking is very important for banks to increase their market share. Therefore, banks should not neglect to develop the infrastructure of their internet banking system. Moreover, if banks continuously improve their telephone banking service, their market share will increase. In addition, POS terminals are convenient platforms for obtaining a cash flow for businesses; hence, when they are developed to be innovative and easy-to-use, firms will welcome them. As a result, banks will enjoy an improved cash flow and plentiful customers, and their market share will grow.

Based on the findings of this study, the ordinary development of mobile banking and out-of-branch services will not result in an increase in a bank's market share, so if banks want to increase their market share through providing better mobile banking and out-of-branch services, they should concentrate on a more radical innovation in these services instead of incremental innovation.

Developing innovative banking services seems vital, since increasing market share is essential for every financial organization, including banks. The findings of this study are useful for managers of both newly founded banks and extant banks, especially those working in developing countries.

\section{Limitations and suggestions for future research}

This study was performed at Shahr bank, which is one of the most innovative private banks in Iran. Although private banks and nationalized banks can both freely use technological innovation to develop their new financial services, the effect of new banking services on their market share may differ. The choice of bank could be a limitation to this study, and it is recommended that researchers consider both private and public banking systems to study innovative channels and their effects on banking outcomes. In addition, future research can develop this study's theoretical framework to investigate the impact of innovative banking services on other marketing constructs such as customer loyalty, brand equity, and customer's perceived value.

\section{Appendix}

Here, we included the questions used for scaling the development of mobile banking, ATM (out-of-branch) banking, internet banking, telephone banking, POS banking, and market share growth. 


\section{Mobile banking Development Questions.}

\begin{tabular}{|c|c|c|c|}
\hline $\begin{array}{l}\text { To what extent do you agree with the following statements about Shahr Bank } \\
\text { activities in the past } 5 \text { years? }\end{array}$ & Mean & SD & $\begin{array}{l}\text { Loading } \\
\text { factor }\end{array}$ \\
\hline $\begin{array}{l}\text { Shahr Bank has performed a lot of research to promote its mobile banking } \\
\text { services. }\end{array}$ & 3.84 & 1.29 & .93 \\
\hline $\begin{array}{l}\text { Shahr Bank has spent a lot of time on designing, launching, and developing its } \\
\text { mobile banking app. }\end{array}$ & 4.31 & 1.05 & .97 \\
\hline $\begin{array}{l}\text { Shahr Bank has spent a lot of money on designing, launching, and developing its } \\
\text { mobile banking app. }\end{array}$ & 3.01 & 1.24 & .89 \\
\hline $\begin{array}{l}\text { Shahr Bank has tried to provide the necessary information for customers through } \\
\text { SMS in a high-quality and well-differentiated way. }\end{array}$ & 4.06 & 1.08 & .96 \\
\hline $\begin{array}{l}\text { Shahr Bank has taken novel ideas (about mobile banking) into consideration and } \\
\text { tried to take advantage of those benefits. }\end{array}$ & 3.84 & 1.29 & .81 \\
\hline
\end{tabular}

\section{Out-of-branch Banking (ATM) Questions.}

\begin{tabular}{llll}
\hline $\begin{array}{l}\text { To what extent do you agree with the following statements about Shahr Bank } \\
\text { activities during the past } 5 \text { years? }\end{array}$ & Mean SD & $\begin{array}{c}\text { Loading } \\
\text { factor }\end{array}$ \\
1 & Shahr Bank has spent a lot of time developing Net Counters services. & 4.57 .77 .83 \\
2 & Shahr Bank has spent a lot of money developing Net Counters services. & 3.84 & 1.29 .95 \\
3 & Shahr Bank has spent a lot of time developing VTM services. & 4.77 .68 & .81 \\
4 & Shahr Bank has spent a lot of money developing VTM services. & 3.84 & 1.29 .87 \\
5 & Shahr Bank has spent a lot of time developing Cash-In Machines services. & 3.84 & 1.29 .96 \\
6 & Shahr Bank has spent a lot of money developing Cash-In Machines services. & 3.84 & 1.29 .95 \\
7 & Shahr Bank has spent a lot of time developing Auto Bank services. & 3.00 & 1.24 .79 \\
8 & Shahr Bank has spent a lot of money developing Auto Bank services. & 3.84 & 1.29 .91 \\
9 & Shahr Bank has spent a lot of time developing ATM services. & 4.86 & .55 \\
10 & Shahr Bank has spent a lot of money developing ATM services. & 3.94 \\
11 & The number of Shahr Bank's Out of Branch service machines has increased & 4.31 & 1.05 .91
\end{tabular}

\section{Internet Banking Questions.}

\begin{tabular}{lll}
\hline $\begin{array}{l}\text { To what extent you agree with the following statements about Shahr Bank } \\
\text { activities during the past 5 years? }\end{array}$ & Mean SD & $\begin{array}{l}\text { Loading } \\
\text { factor }\end{array}$ \\
1 Shahr Bank has spent a lot of time developing Internet Bank services. & 3.84 & 1.29 .90 \\
2 Shahr Bank has spent a lot of money developing Internet Bank services. & 4.26 & .91 .86 \\
3 Shahr Bank has continuously improved its internet bank's website UI and UX. & 3.84 & 1.29 .86 \\
4 Shahr Bank has spent a lot of time developing Mobile Internet Bank services. & 4.31 & 1.05 .94 \\
5 Shahr Bank has spent a lot of money developing Mobile Internet Bank services. & 3.00 & 1.24 .90 \\
6 Shahr Bank has spent a lot of money its Internet Bank and "Mobile Internet Bank" & 4.06 & 1.08 .81 \\
&
\end{tabular}

\section{Telephone Banking Questions.}

\begin{tabular}{lcc}
\hline To what extent you agree with the following statements about Shahr Bank & Mean SD & $\begin{array}{l}\text { Loading } \\
\text { factor }\end{array}$ \\
activities during the past 5 years? & 4.86 & .55 \\
1 Shahr Bank has spent a lot of time developing Telephone Bank terminals. & .96 \\
2 Shahr Bank has spent a lot of money developing Telephone Bank terminals. & 4.32 & 1.05 .79
\end{tabular}




\section{Appendix (Continued)}

3 Shahr Bank has spent a lot of money on its Telephone Bank terminal

$\begin{array}{lll}4.86 & .55 & .91\end{array}$ maintenance.

\section{POS Banking Questions.}

\begin{tabular}{|c|c|c|c|}
\hline $\begin{array}{l}\text { To what extent you agree with the following statements about Shahr Bank } \\
\text { activities during the past } 5 \text { years? }\end{array}$ & Mean & SD & $\begin{array}{l}\text { Loading } \\
\text { factor }\end{array}$ \\
\hline Shahr Bank has spent a lot of time developing Point of Sale services. & 4.32 & 1.05 & .93 \\
\hline Shahr Bank has spent a lot of money developing Point of Sale services. & 4.86 & .55 & .94 \\
\hline $\begin{array}{l}\text { Shahr Bank has benefitted from the most up-to-date technology in its regular POS } \\
\text { terminals. }\end{array}$ & 4.32 & 1.05 & .88 \\
\hline $\begin{array}{l}\text { Shahr Bank has benefitted from the most up-to-date technology in its wireless } \\
\text { POS terminals. }\end{array}$ & 4.06 & 1.08 & .75 \\
\hline Shahr Bank has benefitted from the most up-to-date technology in its debit cards. & 4.86 & .55 & .91 \\
\hline
\end{tabular}
To what extent you agree with the following statements about the bank during Mean SD Loading
the past 5 years?

\section{There has been a significant increase in the}

1 Current account volume at Shahr Bank.

2 Short-term investment deposit volume at Shahr Bank.

3 Special short-term investment deposit volume at Shahr Bank.

$4.31 \quad 1.05 \quad .93$

4 Long-term investment deposit volume at Shahr Bank.

5 The number of natural customers at Shahr Bank.

6 The number of legal customers at Shahr Bank.

7 The number of point-of-sale terminals that are being used by Shahr Bank's customers

8 The number of debit cards issued by Shahr Bank.

9 The number of gift cards issued by Shahr Bank.

$\begin{array}{lll}4.06 & 1.07 \quad .81\end{array}$

10 The volume of Mudarabah contracts in Shahr Bank.

11 The volume of civil partnership contracts in Shahr Bank.

12 The volume of leasing provided by Shahr Bank.

13 The volume of Jaaleh loans provided by Shahr Bank.

14 The volume of debt purchasing contracts in Shahr Bank

$4.27 \quad .91 \quad .69$

15 The number of letter of guarantees issued by Shahr Bank.

16 The volume of Rial credits opened by Shahr Bank.

17 The volume of loans provided to entrepreneurs by Shahr Bank.

$3.00 \quad 1.24 \quad .71$

\section{Abbreviations}

ATM: Automatic Teller Machine; IT: Information Technology; POS: Point of Sales; SMS: Short Message Service;

TB: Telephone Banking; WAP: Wireless Application Protocol

\section{Acknowledgements}

We thank the anonymous referees for their valuable comments to improve the quality of this paper.

\section{Authors' contributions}

AN analyzed and interpreted all the data, and was a major contributor in writing the manuscript. BM supervised the research. All authors read and approved the final manuscript.

\section{Funding}

We hereby confirm that we did not take advantage of any funding for this research. 
Availability of data and materials

The datasets generated and/or analyzed during the current study are available in the Figshare repository, https:// figshare.com/s/ffca65d6dfd025b76716

\section{Ethics approval and consent to participate}

We agree with all journal ethics, and we declare that we are willing in participation with Financial Innovation.

\section{Consent for publication}

We would like to publish this article in Financial Innovation.

\section{Competing interests}

The authors declare that they have no competing interests.

Received: 15 June 2018 Accepted: 6 January 2020

Published online: 07 February 2020

\section{References}

Abor J (2005) Technological innovations and banking in Ghana: an evaluation of customers' perceptions. IFE Psychologia: Int 13(1):170-187

Agwu E (2018) The role of e-banking on operational efficiency of banks in Nigeria. Basic Res J Bus Manag Acc 6(1):1-10

Alikhani E, Azad N, Mousavi S, Mahmoudzadeh S (2013) The role of personal and social characteristics on acceptance of new telephone banking services. Manag Sci Lett 3(11):2737-2742

Anderson EW, Fornell C, Lehmann DR (1994) Customer satisfaction, market share, and profitability: findings from Sweden. J Mark 58:53-66

Anderson JC, Gerbing DW (1988) Structural equation modeling in practice: A review and recommended two-step approach. Psychol Bull 103(3):411

Argamo HH (2015) The Effect of Agency Banking on The Financial Performance of Commercial Banks in Kenya in 2014: A Case Study of Chase Bank (Doctoral dissertation, United States International University-Africa)

Bahrami HR, Haery FA, Karamad F (2014) Investigated the effective factors in the process of market share increase among the branches of Bank Saderat. Int J Acad Res Econ Manag Sci 3(1):51

Bloemer J, De Ruyter K, Peeters P (1998) Investigating drivers of bank loyalty: the complex relationship between image, service quality and satisfaction. Int J Bank Mark 16(7):276-286

Brown I, Cajee Z, Davies D, Stroebel S (2003) Cell phone banking: predictors of adoption in South Africa-an exploratory study. Int J Inf Manag 23(5):381-394

Buzzell RD, Gale BT, Sultan RG (1975) Market share-a key to profitability. Harv Bus Rev 53(1):97-106

Cetina I, Mihail N (2007) Evaluation of the risk and of the opportunities in launching the new banking services. Theor Appl Econ 9(9 (514)):47-52

Chao X, Kou G, Peng Y, Alsaadi FE (2019) Behavior monitoring methods for trade-based money laundering integrating macro and micro prudential regulation: a case from China. Technological Econ Dev Econ:1-16

Chen Y, Puttitanun T (2005) Intellectual property rights and innovation in developing countries. J Dev Econ 78(2):474-493

Cohen MA, Eliasberg J, Ho T-H (1996) New product development: the performance and time-to-market tradeoff. Manag Sci 42(2):173-186

Davcik NS, Grigoriou N (2016) How Dynamic Marketing Capabilities Affect Market Share Performance Output: An Innovative Brand Oriented Approach Marketing Challenges in a Turbulent Business Environment. Springer, Cham, p 133

DeYoung R, Nolle DE (1996) Foreign-owned banks in the United States: earning market share or buying it? J Money Credit Banking 28(4):622-636

Doyle P, Bridgewater S (2012) Innovation in marketing. Routledge

Dunbar CG (2000) Factors affecting investment bank initial public offering market share. J Financ Econ 55(1):3-41

Felix P (2018) Prospects and challenges of electronic banking in Ghana: the case of zenith Bank. IJAMEE, Sunyani

Gerlach D (2000) Put your money where your mouse is. PC World 18(3):191-197

Ghemawat P (2002) Competition and business strategy in historical perspective. Bus Hist Rev 76(01):37-74

Gomez C (2011) Banking and finance: theory, Law and Practice: PHI Learning PVT. LTD, New Delhi

González ME, Mueller RD, Mack RW (2008) An alternative approach in service quality: an e-banking case study. Qual Manag J 15(1):41

Grant RM (1991) The resource-based theory of competitive advantage: implications for strategy formulation. Calif Manage Rev 33(3):114-135

Gupta MVS (2013) Of the paper: corporate governance in modern banking services: an exploration

Hanafizadeh P, Zare Ravasan A (2018) A model for selecting IT outsourcing strategy: the case of e-banking channels. J Glob Inf Technol Manag 21(2):111-138

Hoehle H, Scornavacca E, Huff S (2012) Three decades of research on consumer adoption and utilization of electronic banking channels: a literature analysis. Decis Support Syst 54(1):122-132

Hosseini SS, Mohammadi S (2012) Review banking on biometric in the world's banks and introducing a biometric model for Iran's banking system. J Basic Appl Sci Res 2(9):9152-9160

Kajuju NK (2016) The Effect of electronic banking on liquidity of commercial banks in Kenya. Doctoral dissertation, School of Business, University of Nairobi

Kaplan RS, Norton DP (1996) The balanced scorecard: translating strategy into action. Harvard Business Review Press, Boston

Kashmari A, Nejad AHG, Nayebyazdi A (2016) Impact of electronic banking innovations on Bank deposit market share. J Int Bank Commerce 12(1):1-12

Khan HH, Ahmad RB, Chan SG (2018) Market structure, bank conduct and bank performance: Evidence from ASEAN. J Policy Model 40(5):934-958

Laukkanen T, Lauronen J (2005) Consumer value creation in mobile banking services. Int J Mob Commun 3(4):325-338 
Li Y, Spigt R, Swinkels L (2017) The impact of FinTech start-ups on incumbent retail banks' share prices. Financ Innov $3(1): 26$ Mahmood YN (2019) The Impact of Quality Service Factors on Banking service Sector Case study in Erbil banks. Tikrit J Adm Econ Sci 2(42):1

Mahmoodi S, Naderi H (2016) Assessment of modern banking services to achieve and realization of E-commerce and its impact on the profitability of banks listed on the Tehran stock exchange. Mod Appl Sci 10(9):263

Mallat N, Rossi M, Tuunainen VK (2004) Mobile banking services. Commun ACM 47(5):42-46

Martins C, Oliveira T, Popovič A (2014) Understanding the internet banking adoption: a unified theory of acceptance and use of technology and perceived risk application. Int J Inf Manag 34(1):1-13

Massoud N, Bernhardt D (2002) "Rip-off" ATM surcharges. Rand J Econ:96-115

Maymand MM, Fard RS (2015) Effect of employee branding on market share in Iranian banking industry (case study: Mellat Bank). J Asian Sci Res 5(1):73

Miranda-Petronella V (2009) E-banking-modern banking services. Econ Sci Ser 18(4):1093-1096

Mols NP (1999) The internet and the banks' strategic distribution channel decisions. Int J Bank Mark 17(6):295-300

Morawczynski, O., \& Pickens, M. (2009). Poor people using mobile financial services: observations on customer usage and impact from M-PESA. Retrieved from

Nui Polatoglu V, Ekin S (2001) An empirical investigation of the Turkish consumers' acceptance of internet banking services. Int J Bank Mark 19(4):156-165

Pousttchi, K., \& Schurig, M. (2004). Assessment of today's mobile banking applications from the view of customer requirements. Paper presented at the system sciences, 2004. Proceedings of the 37th annual Hawaii international conference on

Prugsaapron T (2015) Success factors in developing new banking services: a case study of consumers' perspectives in relation to internet banking service provided by the Bangkok Bank PCL (Bualuang iBanking service)

Rabiu ID, Ladan S, Usman HA, Garba M (2019) Impact of E-banking on the Operational Efficiency of Banks in Nigeria. Int J Acad Res Business Soc Sci 9(2)

Rawash HN (2012) The impact of electronic human resource management on organization's market share: an empirical study on the housing Bank for Trade and Finance in Jordan. Int J Bus Soc Sci 3(24):113-120

Rust RT, Zahorik AJ (1993) Customer satisfaction, customer retention, and market share. J Retail 69(2):193-215

Sakhdari K, Burgers JH (2018) The moderating role of entrepreneurial management in the relationship between absorptive capacity and corporate entrepreneurship: an attention-based view. Int Entrepreneurship Manage J 14(4):927-950

Sarlak MA (2010) E-banking and emerging multidisciplinary processes: social, economical and organizational models: social, Economical and Organizational Models: IGI Global

Sasidharan K, Mathews AK (2008) Financial Services and System. Tata McGraw-hill, New Delhi

Sathye M (1999) Adoption of internet banking by Australian consumers: an empirical investigation. Int J Bank Mark 17(7):324-334

Schierholz R, Laukkanen T (2007) Internet vs mobile banking: comparing customer value perceptions. Bus Process Manag J 13(6):788-797

Scornavacca E Jr, Barnes SJ (2004) M-banking services in Japan: a strategic perspective. Int J Mob Commun 2(1):51-66

Sharma, M., Sharma, C., \& Khan, A. (2019). SMART ATM: Technology Acceptance Modeling and Analysis. Available at SSRN 3356363.

Shen L, Cheung SO (2018) How forming joint ventures may affect market concentration in construction industry? Int J Constr Manag 18(2):151-162

Simpson J (2002) The impact of the internet in banking: observations and evidence from developed and emerging markets. Telematics Inform 19(4):315-330

Singanamalla S, Potluri V, Scott C, Medhi-Thies I (2019) PocketATM: understanding and improving ATM accessibility in India. In: Proceedings of the Tenth International Conference on Information and Communication Technologies and Development. ACM, p 14

Smith DC, Park CW (1992) The effects of brand extensions on market share and advertising efficiency. J Mark Res 29(3):296

Tan M, Teo TS (2000) Factors influencing the adoption of internet banking. J the AIS 1(1es):5

Tash MN, Mahmodpour K, Saravani Z (2014) Evaluation of bank market share and its affective determinants: sepah bank. Kuwait Chapter Arabian J Bus Manage Rev 3(12A):240

Thakur R (2014) What keeps mobile banking customers loyal? Int J Bank Mark 32(7):628-646

Thulani D, Tofara C, Langton R (2008) Adoption and use of internet banking in Zimbabwe: an exploratory study. J Internet Banking Commerce 14(1):1-13

Tiwari R, Buse S, Herstatt C (2007) Mobile services in banking sector: the role of innovative business solutions in generating competitive advantage

von Hippel, E., \& Riggs, W. (1996). A lead user study of electronic home banking services: lessons from the learning curve. Online verfügbar unter http://dspace. mit. edu/handle/1721.1/2627, zuletzt geprüft am, 19, 2007

Yiu CS, Grant K, Edgar D (2007) Factors affecting the adoption of internet banking in Hong Kong-implications for the banking sector. Int J Inf Manag 27(5):336-351

YuSheng K, Ibrahim M (2019) Service innovation, service delivery and customer satisfaction and loyalty in the banking sector of Ghana. Int J Bank Mark 37(5):1215-1233

\section{Publisher's Note}

Springer Nature remains neutral with regard to jurisdictional claims in published maps and institutional affiliations. 